\begin{tabular}{l|ll} 
J B E & $\mid \begin{array}{ll}\text { JOURNAL OF } \\
\text { BIOLOGY }\end{array}$ & $\begin{array}{l}\text { E-ISSN 2656-3436/ P-ISSN 2615-3947 } \\
\text { IAIN KUDUS } \\
\text { Tersedia online: http://journal.iainkudus.ac.id/index.php/jbe }\end{array}$ \\
\hline
\end{tabular}

\title{
Keanekaragaman Tumbuhan di Sekitar Mata Air Sumur Gedhe Desa Tanjungsekar Kecamatan Pucakwangi Kabupaten Pati \\ Dewi Nur Syahidah ${ }^{1}$, Niken Kusumarini ${ }^{2}$ \\ 1,2) Biologi UIN Walisongo Semarang \\ syahida_1808016023@student.walisongo.ac.id, kusumarini.niken@walisongo.ac.id
}

\begin{abstract}
ABSTRAK
Mata air Sumur Gedhe merupakan salah satu sumber air yang digunakan sebagian masyarakat untuk memenuhi kebutuhan memasak, mencuci dan mandi. Terdapat tumbuhan yang sangat beranekaragam di sekitar mata air tersebut. Tujuan dari penelitian ini yaitu untuk mengetahui keanekaragaman tumbuhan yang ada disekitar Sumur Gedhe. Metode penelitian yang digunakan adalah purposive sampling. Dilakukan pula wawancara terhadap masyarakat sekitar untuk mengetahui bagaimana mata air tersebut dijaga dan dilestarikan. Terdapat 56 jenis tumbuhan yang ditemukan disekitar mata air Sumur Gedhe. Upaya pelestarian mata air dapat dilakukan dengan menghindari membuang sampah plastik sembarangan, tidak membuang bahan kimia berbahaya, memanfaatkan air seperlunya saja, dan menjaga tumbuhan yang ada disekitarnya. Sebagian besar tumbuhan yang ditemukan ialah tumbuhan liar. Tumbuhan yang ditemukan memiliki perawakan perdu, perdu merambat, pohon, herba dan herba merambat.
\end{abstract}

Kata kunci: Desa Tanjungsekar, Mata Air, Keanekaragaman, Tumbuhan

\begin{abstract}
Sumur Gedhe's water spring is one of the source used by some local society for cooking, washing and bathing. Around it are diverse plants. The purpose of this research is to tell diversity of plants around Sumur Gedhe. This research method is purposive sampling . Interviews were also conducted with the local society to find out how the water sping was maintained and preserved. There are 56 species of plants are found around Sumur Gedhe. Spring conservation efforts can be done by avoiding littering plastic waste, not disposing of hazardous chemichals, utilizing water as needed and protecting plants around it. Most of them are wild plants. Plants habit were shurb, climbing shurb, tree, herbaceous and herb vines habitus.
\end{abstract}

Keywords: Tanjungsekar Village, Water Spring, Diversity, Plant. 


\section{PENDAHULUAN}

Indonesia mempunyai beberapa keanekaragaman salah satunya yaitu keanekaragaman tumbuhan. Menurut Indrawan (2007) dalam Surya (2017) Indonesia berada pada urutan keempat terbesar didunia yang memiliki hutan hujan tropis cukup luas dan keanekaragaman tumbuhan. Menurut Mashud (2010) dalam Mardiyanti (2013), keanekaragaman tumbuhan ialah keanekaragaman jenis tumbuhan yang ada dalam suatu ekosistem.

Mata air adalah pemunculan air menuju permukaan tanah (Sudarmadji, 2016). Salah satu mata air yang ada di Desa Tanjungsekar adalah Sumur Gedhe. Sumur Gedhe terletak di Dukuh Dayu, Desa Tanjungsekar, Kecamatan Pucakwangi, Kabupaten Pati. Lokasi sumber mata air Sumur Gedhe berada di sebelah utara Dukuh Dayu, jaraknya \pm 150 meter dari permukiman warga, di sebelah timur Sumur Gedhe terdapat sungai yang mengarah ke utara. Sekitar Sumu Gedhe terdapat persawahan. Sumur Gedhe terdiri dari embung dan sumur yang menjadi tempat sebagian masyarakat Dukuh Dayu untuk mendapatkan air. Air tersebut umumnya digunakan untuk kebutuhan mandi, mencuci dan memasak. Mata air perlu dijaga kelestariannya salah satunya dengan menjaga vegetasi yang ada di sekitarnya. Karena vegetasi tersebut berperan dalam menjaga kelestarian dan ketersediaan air tersebut (Ridwan, 2015).

Vegetasi yang terdapat di sekitar sumur dan embung Sumur Gedhe belum diketahui jenisnya. Oleh karena itu, penelitian mengenai keanekaragaman tumbuhan di sekitar mata air Sumur Gedhe Dukuh Dayu Desa Tanjungsekar perlu untuk dilakukan untuk mengetahui keanekaragaman tumbuhan yang ada di sekitar mata air Sumur Gedhe dan untuk mengetahui cara masyarakat desa Tanjungsekar dalam menjaga mata air tersebut.

\section{METODE PENELITIAN}

Penelitian ini dilaksanakan pada bulan Juli sampai Agustus 2020 di sekitar sumber mata air Sumur Gedhe Dukuh Dayu Desa Tanjungsekar Kecamatan Pucakwangi Kabupaten Pati. Alat yang digunakan yaitu kamera, alat tulis dan kantong plastik. Bahan yang digunakan yaitu tumbuhan yang ada di sekitar Sumur Gedhe. Pengambilan sampel menggunakan metode Purposive Sampling. Sampel diambil dari tumbuhan yang ada di sekitar Sumur Gedhe untuk diamati karakter morfologinya kemudian diidentifikasi jenisnya. Beberapa sampel tumbuhan hanya diambil gambarnya karena jangkauannya yang susah ataupun jika tumbuhan hanya ada satu disekitar Sumur Gedhe. Dilakukan pula wawancara dengan tokoh masyarakat untuk mengetahui bagaimana mata air tersebut dijaga.

\section{HASIL DAN PEMBAHASAN}

Tumbuhan yang ada disekitar Sumur Gedhe sangat beragam. Terdapat sekitar 56 spesies tumbuhan berbeda yang telah ditemukan. Dari 56 spesies tumbuhan tersebut memiliki karakter yang berbeda-beda. Hasil observasi dapat dilihat pada tabel 1 berikut. 
Tabel 1. Jenis-jenis tumbuhan yang dijumpai di sekitar mata air Sumur Gedhe

\begin{tabular}{|c|c|c|c|}
\hline No. & Tipe Perawakan & Jenis Tumbuhan & Suku \\
\hline 1. & Pohon & Randu (Ceiba pentandra (L.) Gaertn.) & Malvaceae \\
\hline 2. & Pohon & Kersen (Muntingia calabura L.) & Muntingiaceae \\
\hline 3. & Pohon & $\begin{array}{l}\text { Asam Londo (Pithecellobium dulce } \\
\text { (Roxb.) Benth.) }\end{array}$ & Fabaceae \\
\hline 4. & Pohon & Weru (Albizia procera (Roxb.) Benth.) & Fabaceae \\
\hline 5. & Pohon & (Euonymus hamiltonianus Wall.) & Celastraceae \\
\hline 6. & Pohon & (Bridelia $\mathrm{Sp})$. & Phyllanthaceae \\
\hline 7. & Perdu & $\begin{array}{l}\text { Lamtoro } \\
\text { (Leucaena leucocephala (Lam.) de Wit) }\end{array}$ & Fabaceae \\
\hline 8. & Perdu & $\begin{array}{l}\text { Kembang sepatu } \quad \text { (Hibiscus rosa- } \\
\text { sinensis L.) }\end{array}$ & Malvaceae \\
\hline 9. & Perdu & Cukilan (Allophylus cobbe (L.) Raeusch) & Sapindaceae \\
\hline 10. & Perdu & Tapak liman (Elephantropus scaber L.) & Asteraceae \\
\hline 11. & Perdu & Putri malu besar (Mimosa invisa Colla) & Fabaceae \\
\hline 12. & Perdu & Mangsian (Phyllanthus reticulatus Poir.) & Phyllanthaceae \\
\hline 13. & Perdu & $\begin{array}{l}\text { Biduri } \quad \text { (Calotropis gigantea (L.) } \\
\text { Dryand.) }\end{array}$ & Apocynaceae \\
\hline 14. & Perdu & Walikukun (Schoutenia ovata Korth) & Malvaceae \\
\hline 15. & Perdu & $\begin{array}{l}\text { Rumput Minjangan (Chromolaena } \\
\text { odorata (L.) R.M.King \& H.Rob.) }\end{array}$ & Asteraceae \\
\hline 16. & Perdu & Jarong (Achyranthes aspera L.) & Amaranthaceae \\
\hline 17. & Perdu & Sidaguri (Sida rhombifolia L.) & Malvaceae \\
\hline 18. & Perdu & Landep (Barleria prionitis L.) & Acanthaceae \\
\hline & Perdu & Godong Puser (Hyptis capitata Jacq.) & Lamiaceae \\
\hline 20. & Perdu & (Flemingia sp.) & Fabaceae \\
\hline 21. & Perdu & Pulutan (Urena lobata L.) & Malvaceae \\
\hline & Perdu & (Uraria sp.) & Fabaceae \\
\hline & Perdu & Awar-awar (Ficus septicum Burm. F) & Moraceae \\
\hline & Perdu & (Desmodium gangeticum (L.) DC.) & Fabaceae \\
\hline & Herba & $\begin{array}{l}\text { Rumput kenop (Gomphrena celosoides } \\
\text { Mart.) }\end{array}$ & Amaranthaceae \\
\hline & Herba & Jelantir (Erigeron sumatrensis Retz.) & Asteraceae \\
\hline & Herba & Sapu Manis (Scoparia dulcis L.) & Plantaginaceae \\
\hline & Herba & $\begin{array}{l}\text { Jotang kuda (Synedrella nodiflora (L.) } \\
\text { Gaertn.) }\end{array}$ & Asteraceae \\
\hline
\end{tabular}




\begin{tabular}{|c|c|c|}
\hline 29. Herba & $\begin{array}{l}\text { Tempuh wiyang (Emilia sonchifolia (L.) } \\
\text { DC. ex DC.) }\end{array}$ & Asteraceae \\
\hline Herba & $\begin{array}{l}\text { Sangket (Basilicum polystachyon (L.) } \\
\text { Moench) }\end{array}$ & Lamiaceae \\
\hline Herba & Pletikan (Ruellia tuberosa L.) & Acanthaceae \\
\hline Herba & $\begin{array}{l}\text { Alang-alang (Imperata cylindrical (L) } \\
\text { Raeusch.) }\end{array}$ & Poaceae \\
\hline Herba & Gelagah (Saccharum spontaneum L) & Poaceae \\
\hline Herba & Patikan kebo (Euphorbia hirta L) & Euphorbiaceae \\
\hline Herba & $\begin{array}{l}\text { Pacing (Cheilocostus speciosus } \\
\text { (J.Koenig) C.D.Specht) }\end{array}$ & Costaceae \\
\hline Herba & Meniran (Phyllanthus urinaria $\mathrm{L}$ ) & Phyllanthaceae \\
\hline Herba & Bandotan (Ageratum conyzoides (L.) L.) & Asteraceae \\
\hline Herba & $\begin{array}{l}\text { Rumput lulangan (Eleusine indica (L.) } \\
\text { Gaertn.) }\end{array}$ & Poaceae \\
\hline 39. Herba & $\begin{array}{l}\text { Rumput kerbau (Lophatherum gracile } \\
\text { Brogn.) }\end{array}$ & Poaceae \\
\hline 40. Herba & Gletang (Tridax procumbens (L.) L.) & Asteraceae \\
\hline Herba & $\begin{array}{lr}\text { Rumput } & \text { tuton } \\
\text { (Dactyloctenium aegyptium (L.) Willd.) }\end{array}$ & Poaceae \\
\hline 42. Herba & $\begin{array}{ll}\text { Rumput } & \text { kawatan } \\
\text { (Cynodon dactylon (L.) Pers.) } & \\
\end{array}$ & Poaceae \\
\hline Herba & $\begin{array}{l}\text { Rumput kolomento (Leersia hexandra } \\
\text { Sw.) }\end{array}$ & Poaceae \\
\hline Herba & $\begin{array}{l}\text { Rumput paitan } \\
\text { (Paspalum conjugatum P.J.Bergius) }\end{array}$ & Poaceae \\
\hline Herba & Bayam (Amaranthus sp.) & Amaranthaceae \\
\hline 46. Herba & Rumput teki (Cyperus rotundus L.) & Cyperaceae \\
\hline 47. Herba & $\begin{array}{l}\text { Rumput blembem (Ischaemum rugosum } \\
\text { Salisb.) }\end{array}$ & Poaceae \\
\hline Herba & $\begin{array}{l}\text { Rumput jagungan } \\
\text { (Brachiaria plantaginea (Link) Hitchc.) }\end{array}$ & Poaceae \\
\hline Herba & Pegagan (Centella asiatica (L.) Urb) & Apiaceae \\
\hline Herba merambat & Lembayung (Basella sp.) & Basellaceae \\
\hline Herba merambat & Ipomea sp. & Convolvulaceae \\
\hline Herba merambat & Cyclea sp. & Menispermaceae \\
\hline Herba merambat & Lawatan (Ipomea sp.) & Convolvulaceae \\
\hline Herba merambat & Prapasan (Momordica sp.) & Cucurbitaceae \\
\hline
\end{tabular}




\begin{tabular}{llll}
\hline 55. & Herba merambat & Rambusa (Passiflora foetida L.) & Passifloraceae \\
\hline 56. & Perdu merambat & Kembang telang (Clitoria ternatea L.) & Fabaceae \\
\hline
\end{tabular}

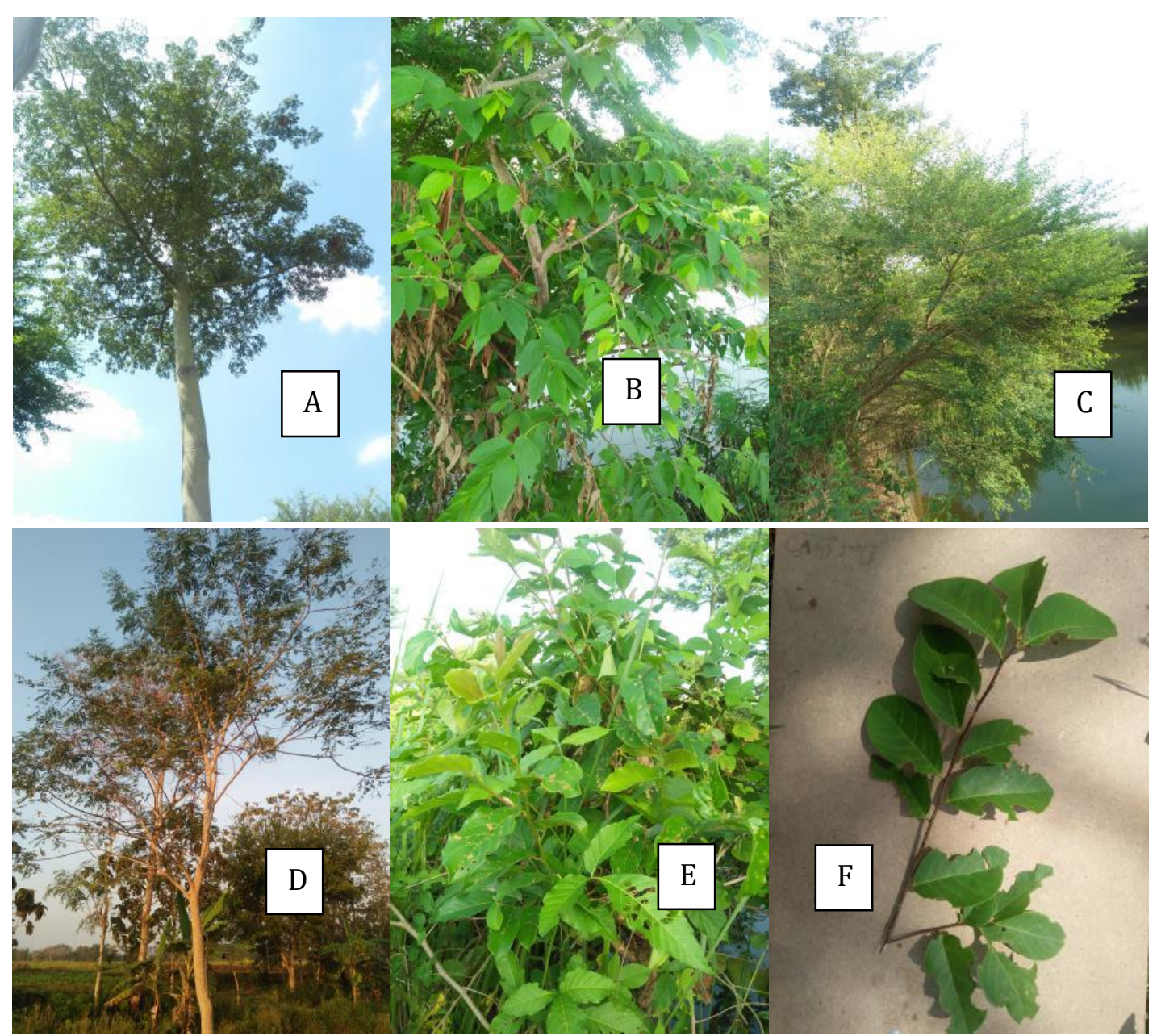

Gambar 1. Jenis tumbuhan berperawakan pohon yang dijumpai di sekitar mata air Sumur Gedhe.Keterangan: A. Randu (Ceiba pentandra (L.) Gaertn.) B. Kersen (Muntingia calabura L.) C. Asam Londo (Pithecellobium dulce (Roxb.) Benth.) D. Weru (Albizia procera (Roxb.) Benth.) E. (Euonymus hamiltonianus Wall.) F. (Bridelia sp.) 

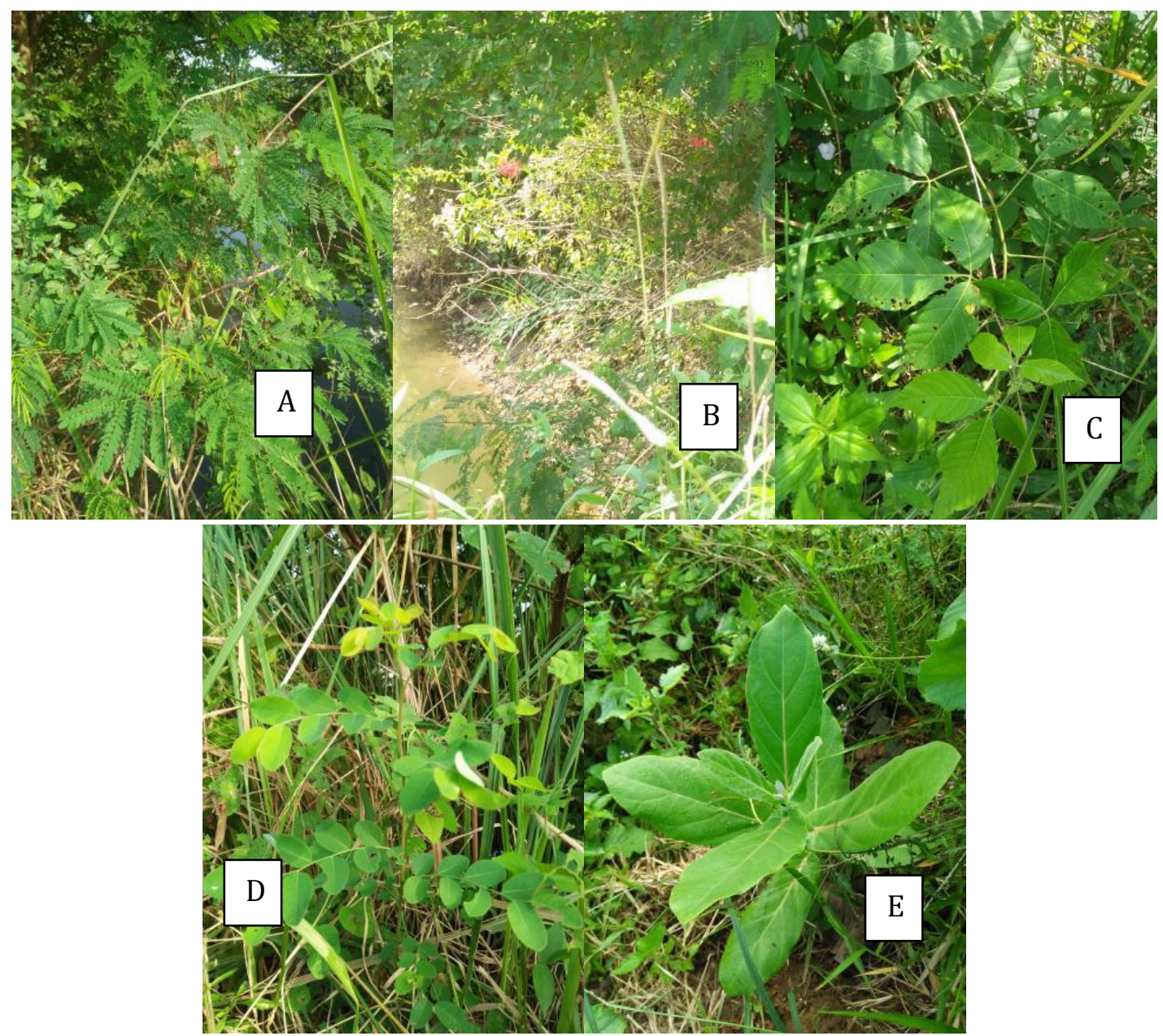

Gambar 2. Jenis tumbuhan berperawakan perdu yang dijumpai di sekitar mata air Sumur Gedhe. Keterangan: A. Lamtoro (Leucaena leucocephala (Lam.) de Wit) B. Kembang Sepatu (Hibiscus rosa-sinensis L.) C. Cukilan (Allophylus cobbe (L.) Raeusch) D. Mangsian (Phyllanthus reticulatus Poir.) E. Biduri (Calotropis gigantea (L.) Dryand.) 


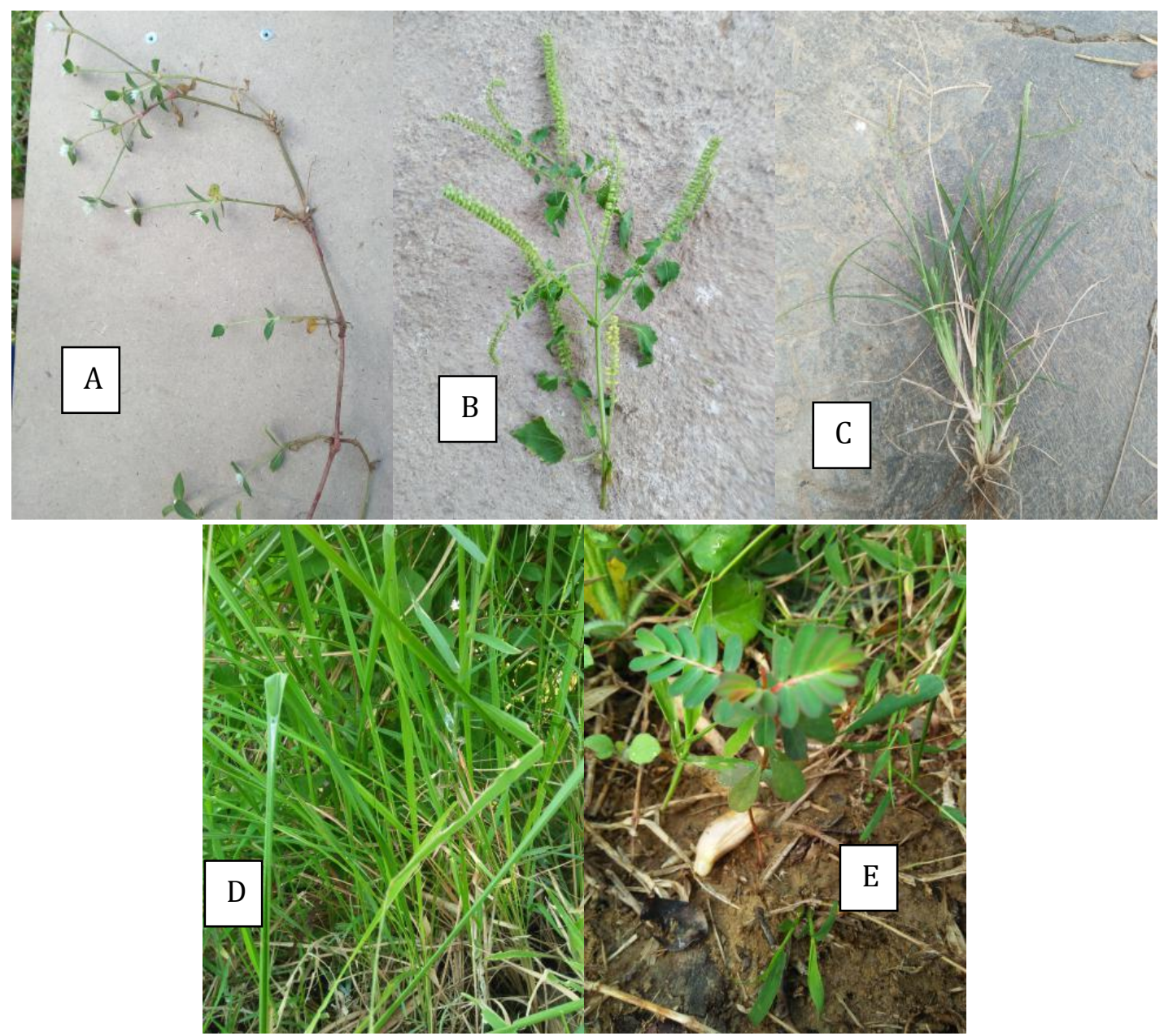

Gambar 3. Jenis tumbuhan berperawakan herba yang dijumpai di sekitar mata air Sumur Gedhe. Keterangan: A. Rumput Kenop (Gomphrena celosoides Mart.) B. Sangket (Basilicum polystachyon (L.) Moench) C. Rumput Lulangan (Eleusine indica (L.) Gaertn.) D. Alang-alang (Imperata cylindrical (L) Raeusch.) E. Meniran (Phyllanthus urinaria L) 

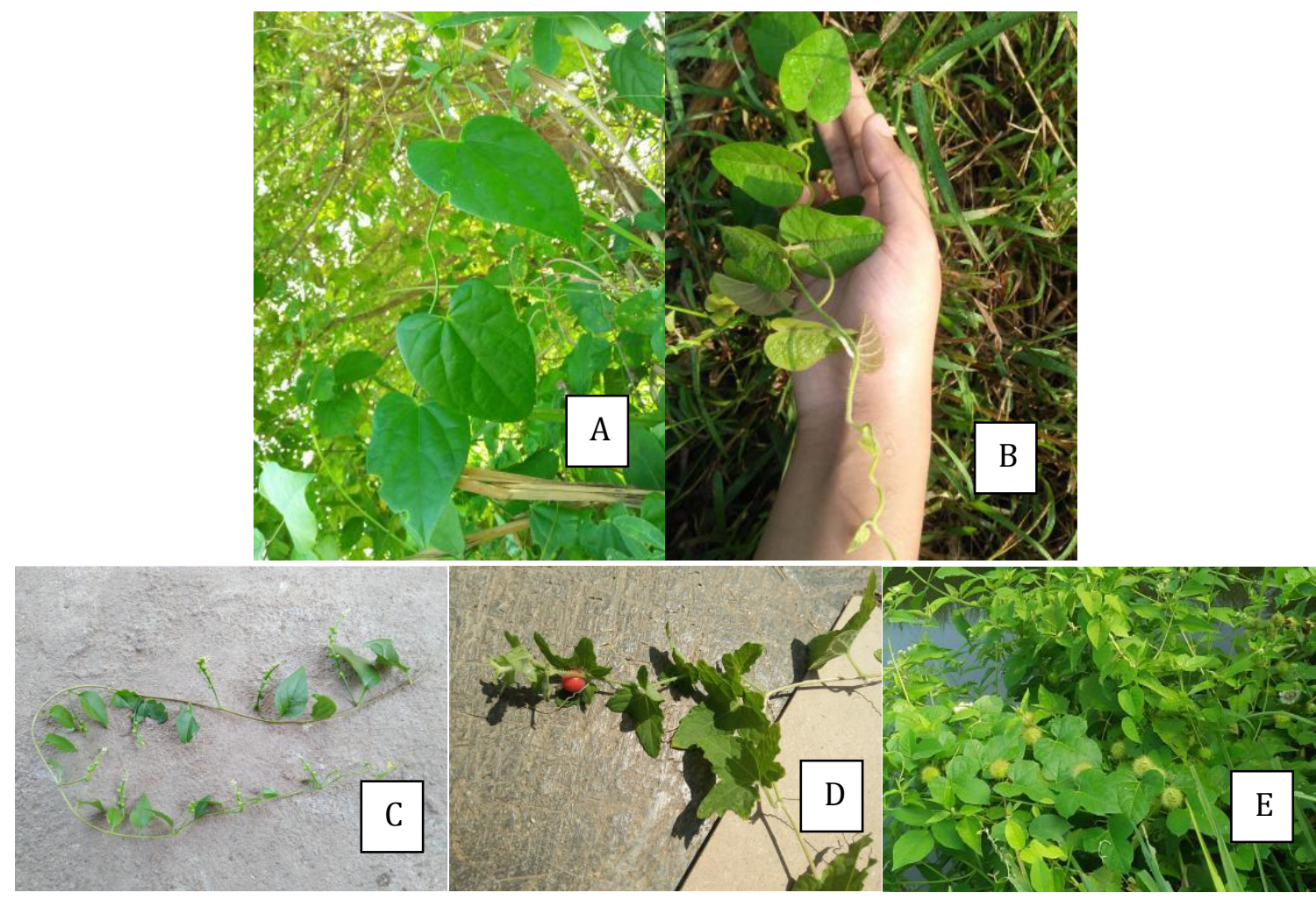

Gambar 4. Jenis tumbuhan berperawakan herba merambat yang dijumpai di sekitar mata air Sumur Gedhe. Keterangan: A. Cyclea sp. B. Lawatan (Ipomea sp.) C. Lembayung (Basella sp.). D. Prapasan (Momordica sp.) E. Rambusa (Passiflora foetida L.)

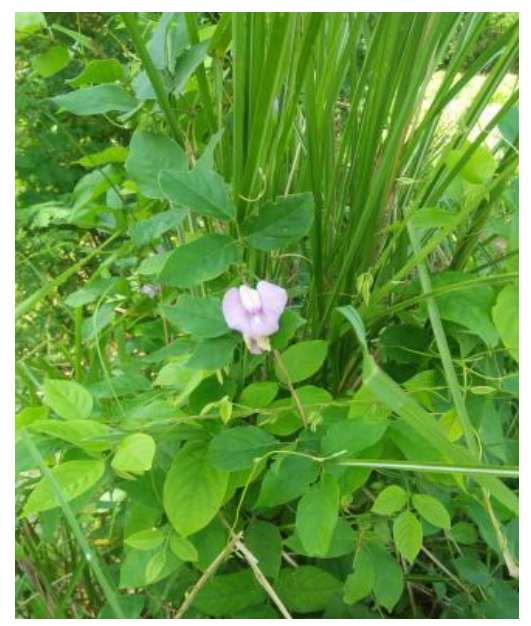

Gambar 5. Jenis tumbuhan berperawakan perdu merambat yang dijumpai di sekitar mata air Sumur Gedhe. Keterangan: Kembang telang (Clitoria ternatea L.)

Sebanyak 56 jenis tumbuhan tersebut dapat dikelompokkan menjadi 25 suku. Anggota terbesar berasal dari suku Poaceae sebanyak 10 jenis, selanjutnya Fabaceae 8 jenis, 
Asteraceae 7 jenis, Malvaceae 5 jenis, Amaranthaceae 3 jenis. Suku Phyllanthaceae, Convolvulaceae dan Lamiaceae masing-masing sebanyak 2 jenis, sedangkan 17 suku lainnya masing-masing beranggotakan 1 jenis. Berdasarkan hasil pengamatan, tumbuhan yang ditemukan sebagian besar adalah tumbuhan liar. Tumbuhan liar merupakan tanaman pengganggu atau disebut juga gulma (Badrunasar, 2016). Berdasarkan tumbuhan liar yang ditemukan, beberapa memiliki manfaat sebagai obat seperti meniran, godong puser, rumput lulangan, sidaguri, patikan kebo, babandotan, tapak liman, pegagan, rambusa dan tempuh wiyang. Namun karena kurangnya pengetahuan tentang manfaat dari tumbuhan obat, beberapa hanya dimanfaatkan sebagai pakan ternak oleh sebagian warga. Pakan ternak umumnya memanfaatkan bagian tanaman yang berupa daun. Selain itu, tumbuhan yang berperawakan pohon dapat bermanfaat sebagai peneduh.

Terdapat 6 jenis tumbuhan yang memiliki perawakan pohon, sedangkan sisanya merupakan perdu, perdu merambat, herba dan herba merambat. Perawakan herba mempunyai ciri-ciri kurang atau tidak terdapat jaringan berkayu seperti rumput teki. Perawakan pohon merupakan tumbuhan berkayu yang mempunyai batang utama sebagai pembeda dari perdu (Azrai, 2015). Perawakan perdu mempunyai ciri-ciri tumbuhan berkayu, bercabang lebih banyak dan lebih pendek dibanding pohon (Badrunasar, 2016). Tumbuhan merambat dibedakan menjadi vine dan liana. Vine merupakan tumbuhan merambat herba dan semi berkayu, contohnya rambusa dan lembayung. Sedangkan liana merupakan tumbuhan merambat berkayu atau disebut perdu merambat, contohnya kembang telang (Rahayu, 2017). Vegetasi yang ditemukan di sekitar Sumur Gedhe tersebut mempengaruhi kondisi air sumur.

Kondisi air di Sumur Gedhe cukup jernih, namun air pada bagian embungnya agak berwarna hijau kecoklatan tetapi ketika diambil akan tampak jernih. Biasanya warga yang mengambil air akan menimba melalui bagian sumur menggunakan katrol timba. Meskipun dikelilingi area persawahan, air di Sumur Gedhe tidak diperbolehkan untuk digunakan mengairi sawah. Warga lebih memilih menaman padi pada musim hujan. Sedangkan pada musim kemarau sawah-sawah ditanami kacang-kacangan, ubi jalar atau dibiarkan begitu saja.

Intensitas curah hujan di Kabupaten Pati rata-rata sekitar $192 \mathrm{~mm}$ dengan 60 hari per tahun (sippa.ciptakarya.pu.go.id) dan tergolong sedang/menengah, sehingga keberadaan mata air Sumur Gedhe yang menghasilkan air sepanjang tahun cukup vital bagi kebutuhan penduduk sekitar untuk keperluan mencuci, memasak dan mandi. Masyarakat sekitar sangat menjaga mata air Sumur Gedhe. Hal tersebut dikarenakan oleh mata air tersebut terletak cukup dekat dengan permukiman warga sehingga cukup mudah untuk mendapatkan air dalam memenuhi kebutuhan mereka. Menurut Kadam (2020) berikut beberapa upaya yang dapat dilakukan untuk menjaga mata air tersebut, diantaranya yaitu menghindari membuang sampah plastik sembarangan, tidak membuang bahan kimia berbahaya, memanfaatkan air seperlunya saja serta menjaga tumbuhan yang ada di sekitar Sumur Gedhe. 
Intensitas curah hujan yang tergolong sedang/menengah menyebabkan air di Sumur Gedhe akan menyusut hingga hampir habis pada musim kemarau panjang. Demikian pula dengan tumbuhan di sekitarnya. Tumbuhan yang tidak dapat bertahan hidup pada musim kemarau akan mengering dan mati. Sehingga pada musim kemarau akan lebih sedikit tumbuhan yang ditemukan.

Pohon berperan penting dalam menjaga kelestarian suatu mata air. Pohon dapat membantu peresapan air kedalam tanah sehingga terdapat cadangan air yang tersimpan. Selain itu pohon yang ada di sekitar mata air dapat membantu menjaga kesimbangan air karena rimbunnya pohon dapat menurunkan suhu dan meningkatkan kelembapan sehingga mengurangi laju penguapan. Maka dari itu, perlu dilakukan penanaman pohon dengan maksud untuk menjaga keberlangsungan mata air (Yuliantoro, 2016).

\section{SIMPULAN}

Ditemukan 56 jenis tumbuhan di sekitar mata air Sumur Gedhe. Sebagian besar tumbuhan yang ditemukan merupakan tumbuhan liar dengan perawakan pohon, perdu, perdu merambat, herba dan herba merambat. Upaya masyarakat dalam menjaga mata air dan lingkungan sekitarnya adalah dengan menghindari membuang sampah plastik sembarangan, tidak membuang bahan kimia berbahaya, serta memanfaatkan air seperlunya.

SARAN

Perlu dilakukan penanaman pohon di sekitar mata air untuk mempertahankan dan melestarikan kelangsungan mata air sepanjang tahun. 


\section{DAFTAR PUSTAKA}

Azrai, Eka Putri., dan Erna Heryanti. 2015. Biodiversitas Tumbuhan Semak di Hutan Tropis Dataran Rendah Cagar Alam Pangandaran, Jawa Barat. Prosiding Semirata 2015 Bidang MIPA BKS-PTN Barat Universitas Tanjungpura Pontianak. 403-408.

Badrunasar, Anas., dan Harry Budi Santoso. 2016. Tumbuhan Liar Berkhasiat Obat. Bogor: Forda Press.

Kadam. 2020. Hasil Wawancara Upaya Pelestarian Mata Air Sumur Gedhe. Pati

Mardiyanti, Devi Erlinda., DKK. 2013. Dinamika Keanekaragaman Spesies Tumbuhan Pasca Pertanaman Padi. Jurnal Produksi Tanaman. Vol 1 (1): 24-35.

Rahayu, Nani., DKK. 2017. Karakteristik Komunitas Tumbuhan Merambat di Suaka Margasatwa Pulau Rambut. Media Konservasi. Vol 22(1): 1-10.

Ridwan, Muhammad., dan Diagal Wisnu Pamungkas. 2015. Keanekaragaman Vegetasi Pohon di Sekitar Sumber Mata Air di Kecamatan Panekan, Kabupaten Magetan, Jawa Timur. PROS SEM NAS MASY BIODIV INDON. Vol 1 (6): 1375-1379 (ISSN: 24078050).

Sudarmadji., DKK. 2016. Pengelolaan Mata Air Untuk Penyediaan Air Rumah Tangga Berkelanjutan di Lereng Selatan Gunung Api Merapi. Jurnal Manusia dan Lingkungan. Vol 23 (1): 102-110.

Surya, Muhammad Imam., dan Inggit Puji Astuti. 2017. Keanekaragaman dan Potensi Tumbuhan di Kawasan Hutan Lindung Guning Pesangi, Lampung Barat. PROS SEM NAS MASY BIODIV INDON. Vol 3 (2): 211-215 (ISSN: 2407-8050).

Tim Penyusun. 2017. Penyusunan Revisi Rencana Program Investasi Jangka Menengah (RPIJM) Bidang Cipta Karya Kabupaten Pati Tahun 2015-2019. Pati: Pemerintah Kabupaten Pati. sippa.ciptakarya.pu.go.id

Yuliantoro, Dody., DKK. 2016. Pohon Sahabat Air. Surakarta: Balai Penelitian dan Pengembangan Teknologi Pengelolaan Daerah Aliran Sungai. 